Jurnal Fokus Manajemen Bisnis
Vol.11, No.1, Maret 2021, pp. 22-41
https://doi.org/10.12928//fokus.v11i1.3734
http://journal2.uad.ac.id/index.php/fokus
Universitas
Ahmad Dahlan

\title{
PENGARUH KREDIBILITAS INFLUENCER PADA EFEKTIVITAS IKLAN MEDIA SOSIAL INSTAGRAM DALAM MEMBENTUK MINAT BELI KONSUMEN (STUDI PADA PENGIKUT INSTAGRAM AYUDIA BING SLAMET)
}

\author{
Alhensa Ferninda Kencana Jelita', Hasnah Rimiyati2,"* \\ Universitas Muhammadiyah Yogyakarta \\ hasnah_rimiyati@umy.ac.id \\ *Hasnah Rimiyati
}

Article history

Received 2021-02-23

Revised 2021-03-20

Accepted 2021-03-22

Keywords

Credibility

Attractiveness

Trust

Expertise

Attitude Towards Advertising

Purchase Interest
This study aims to analyze the influence of influencers credibility on the effectiveness of Instagram social media advertising in shaping consumer buying interest (Study on Instagram followers Ayudia Bing Slamet). The subjects in this study were students using social media Instagram who were in the Special Region of Yogyakarta. This research was conducted with a sample size of 200 respondents who were determined by sampling technique using non probability sampling technique with purposive sampling method and distributing questionnaires to respondents using Google Forms. The analytical tool used is Structural Equation Modeling (SEM) with the AMOS 24 application program. Based on the analysis, it was found that the attractiveness of influencers had a positive effect on consumer attitudes towards advertising, trustworthiness towards influencers had a positive effect on consumer attitudes towards advertising, influencer expertise had a positive effect on consumer attitudes towards advertising, and attitudes towards advertising had a positive effect on buying interest.

This is an open-access article under the CC-BY-SA license.

\section{Pendahuluan}

Dunia teknologi saat ini telah berkembang sangat pesat, terutama dalam media periklanan dan pemasaran bagi suatu perusahaan. Perusahaan saat ini dituntut untuk lebih kreatif dalam melakukan strategi pemasaran dan periklanan dan dalam penyampaiannya harus dilakukan dengan penuh pertimbangan. Strategi pemasaran merupakan salah satu faktor penting yang bisa membuat suatu perusahaan sukses dalam menghadapi persaingan, menciptakan keunggulan kompetitif, meraih konsumen baru, dan mempertahankan konsumen yang loyal.

Influencer media sosial telah muncul sebagai endorser pihak ketiga yang dinamis. Memanfaatkan sebagian besar platform media sosial seperti Instagram, Twitter, Facebook, dan Youtube. Influencer media sosial tepat digunakan untuk mempublikasikan informasi produk dan promosi terbaru kepada pengikut online atau followers. Influencer media sosial biasanya terlibat dengan pengikut mereka dengan memperbarui secara teratur mengenai informasi terbaru. Kekuatan persuasif dari influencer media sosial menjadi hal yang strategis bagi manajemen pemasaran untuk mampu menentukan influencer yang relevan dengan suatu merek atau organisasi.

Dalam pemasaran, dukungan influencer memainkan peran penting dalam mencapai 
kebaikan reputasi perusahaan dan sasaran bisnis. Beberapa tahun terakhir, influencer media sosial telah memantapkan diri mereka sebagai endorser potensial dengan menghasilkan sejumlah followers atau peminat dibandingkan dengan strategi pemasaran lainnya, seperti contohnya celebrity endorsement, dan dianggap menjadi tren pemasaran yang paling efisien dan efektif. Influencer sosial media mampu memberikan return on investment (ROI) 11 kali lebih tinggi dibandingkan dengan digital marketing (Lim, et al., 2017). Selain itu, influencer media sosial juga dapat menampilkan hasil yang menarik dalam liputan media dan persuasi konsumen.

Menurut Shimp (2014) kredibilitas influencer diartikan sebagai sifat yang dimiliki oleh seseorang yang nantinya dapat menimbulkan rasa percaya terhadap dirinya atas apa yang diperbuat baik sebuah verbal dan non verbal yang disampaikan melalui iklan. Kredibilitas mengacu kepada kecenderungan untuk percaya kepada seseorang. Seorang Influencer dapat mempengaruhi orang lain melalui perkataannya. Influencer bukan hanya seorang selebriti, akan tetapi semua orang bisa menjadi influencer jika orang tersebut dapat mempengaruhi orang lain dan memiliki followers yang banyak.

Perusahaan menggunakan influencer bertujuan untuk untuk meningkatkan awareness, mengedukasi target konsumen, meningkatkan followers dan meningkatkan minat beli. Menurut Kotler dan Amstrong (2016) minat beli konsumen adalah rangsangan yang timbul setelah melihat produk, dari situ timbul ketertarikan agar mencoba produk tersebut sampai akhirnya timbul rasa ingin memiliki.

Berdasarkan prinsip pemasaran influencer, perusahaan umumnya mengundang media sosial influencer seperti vlogger dengan ribuan pengikut di akun media sosial mereka sebagai duta merek suatu perusahaan tersebut. Pesan yang disampaikan oleh influencer media sosial sering dianggap lebih dapat diandalkan dan menarik konsumen, dan telah didukung oleh $82 \%$ dari jajak pendapat pengikut, dimana konsumen dilaporkan lebih cenderung mengikuti pengaruh rekomendasi favorit mereka. Dibandingkan dengan strategi celebrity endorsement, penggunaan influencer media sosial dianggap lebih kredibel, dapat dipercaya, dan berpengetahuan karena keramahan mereka dalam membangun hubungan dengan konsumen, terutama untuk bisnis yang menargetkan generasi muda zaman sekarang.

Dukungan selebriti lebih berperan dalam mengangkat kesadaran merek di antara konsumen, sementara pengaruh media sosial memainkan peran yang sangat signifikan yaitu peran dalam mendorong keterlibatan produk dan loyalitas merek. Influencer media sosial sebagai endorser merek telah tumbuh dan lebih banyak dicari terutama di kalangan bisnis online yang baru.

Penelitian ini mengacu pada penelitian yang pernah dilakukan Sarashadi dan Dewi (2018). Perbedaan penelitian ini dengan penelitian sebelumnya terletak pada subjek yang diubah menjadi Instagram dan objek ditambahkan yaitu seorang influencer Ayudia Bing Slamet.

Ayudia merupakan salah satu influencer Indonesia yang berpengaruh besar. Ayudia dikenal sebagai artis sekaligus influencer dengan 2,2 juta followers di Instagram dan sekarang juga telah mempunyai channel YouTube dengan 882 ribu subcribers. Ayudia memiliki pesona yang kuat untuk membuat banyak orang tertarik pada produk yang ia pakai. Adapun gaya fashion yang dikenakan oleh Ayudia, membuat banyak orang penasaran dan ia pun membuat beberapa review produk di akun Instagramnya. Ayudia sering dijadikan inspirasi oleh kaum wanita Indonesia yang kagum terhadapnya. Selain kecantikannya, sifat baik Ayudia sering menjadi inspirasi. Ayudia sering dijadikan model untuk produk fashion hijab serta produk skincare dan make up. Tak jarang ia mengunggah selfie atau bahkan photoshoot miliknya. Ayudia juga sering mengunggah hasil jepretan kameranya di akun Instagram miliknya. Ayudia juga merambah ke dunia musik bersama dengan band Dengarkan Dia. Setelah berhasil meluncurkan buku Teman Tapi Menikah bersama suaminya, Ditto, Ayudia juga aktif di YouTube '\#temantapimenikah' yang kerap menampilkan kegiatan travelling-nya. 
Penelitian ini berusaha untuk memahami gagasan influencer media sosial dengan menguji efek pada sikap konsumen dan niat beli. Kredibilitas influencer menginterpretasikan niat pembelian dengan menilai perasaan konsumen mengenai seberapa relevan Influencer menjadi panutan dalam potensi niat pembelian. Selanjutnya, efektivitas influencer dari media sosial atas niat pembelian melalui sikap pelanggan dapat berpotensi menawarkan wawasan berharga untuk pemasaran yang praktis, dimana mereka dapat mengembangkan strategi promosi untuk membentuk citra yang positif dan pengambilan keputusan konsumen yang berdampak terhadap produk dan layanan mereka.

\section{Review Literatur dan Hipotesis}

\subsection{Landasan Teori}

\subsubsection{Influencer Media Sosial}

Influencer adalah seseorang atau figure dalam kehidupan yang memiliki jumlah pengikut yang banyak atau signifikan di media sosial dan sesuatu yang mereka sampaikan dapat mempengaruhi para pengikutnya (Hariyanti dan Wipraja, 2018). Definisi media sosial menurut Tjiptono (2016) adalah suatu teknologi yang memiliki basis internet yang memfasilitasi percakapan. Influencer marketing menggunakan cara dengan metode-metode menunjuk orang atau figur yang dianggap memiliki pengaruh besar di antara masyarakat atau segmen target konsumen yang akan dituju dan dapat menjadi sasaran promosi dari merek tersebut.

\subsubsection{Kredibilitas}

Menurut Shimp (2014) kredibilitas adalah hal yang mengacu kepada kepercayaan terhadap seseorang. Shimp (2014) menambahkan dalam mengenalkan suatu produk atau merek seorang pemasar atau produsen seringkali menggunakan berbagai tokoh yang sangat terkenal di kalangan konsumen popular atau yang dianggap memiliki pengaruh yang besar untuk mempengaruhi orang. Dapat kita lihat banyak dari iklan yang menggunakan para tokoh dalam mengiklankan produk mereka. Informasi yang disampaikan oleh pihak yang dianggap kredibel (seperti influencer sosial media) dapat mempengaruhi keyakinan, opini, sikap, dan perilaku konsumen (Wang et al., 2017).

\subsubsection{Efektivitas Iklan}

Pengukuran efektivitas sangat penting dilakukan. Tanpa dilakukannya pengukuran efektivitas tersebut akan sulit diketahui apakah tujuan perusahaan dapat dicapai atau tidak. Di era modern ini mendapatkan informasi seperti iklan adalah alat yang paling mudah dan efektif untuk menginformasi produk secara umum, serta membuat produk mudah diingat oleh konsumen. Zhang dan Ming-Yuan (2018) menggambarkan efektivitas iklan dimulai ketika konsumen memproses apa yang mereka lihat melalui pesan iklan yang kemudian diakhiri dengan kesuksesan dalam mempersuasi konsumen dan mencapai tujuan pemasaran. Pengukuran efektivitas iklan dapat dikaji baik secara psikologis (perilaku) maupun secara medis neuroscience seperti respon kulit, respon gerakan mata, dan respon gerakan wajah (Li et al., 2018).

\subsubsection{Sikap terhadap Iklan}

Menurut Kotler dan Amstrong (2016) sikap terhadap iklan adalah tanggapan terhadap objek yang disiapkan oleh jiwa dan pikiran yang diorganisasikan melalui pengalaman dan mempengaruhi perilaku secara langsung. Keadaan jiwa tersebut sangat dipengaruhi oleh tradisi, kebiasaan kebudayaan, dan lingkungan sosialnya (Kotler dan Amstrong, 2016). Kotler dan Keller (2016) mengatakan iklan adalah segala bentuk komunikasi nonpribadi dan promosi gagasan, produk, atau jasa yang dibayarkan oleh sponsor tertentu atau yang diketahui. Shekari et al., (2020) 
mengungkapkan beberapa faktor yang mempengaruhi sikap terhadap iklan antara lain manfaat yang dirasakan konsumen, kualitas iklan yang disampaikan, kesadaran pada level sosial, dan monetisasi konsumen atas iklan tersebut.

\subsubsection{Minat Beli Konsumen}

Menurut Kotler dan Keller (2016) minat beli konsumen adalah keinginan dari konsumen dimana konsumen memiliki perilaku dalam memilih dan mengkonsumsi suatu produk. Pendapat lain dari Morissan (2014) minat beli adalah tahap dari keputusan pembelian dimana suatu titik dalam proses pembelian, konsumen harus berhenti melakukan evaluasi, konsumen mulai mengarah pada minat dan keinginan untuk membeli dengan kecenderungan untuk membeli merek tertentu.

\subsection{Pengembangan Hipotesis}

2.2.1. Pengaruh Positif Daya Tarik (Attractiveness) Influencer pada Sikap Konsumen terhadap Iklan

Menurut Shimp (2014) terdapat salah satu komponen kredibilitas yaitu attractiveness (daya tarik) mengacu pada sejumlah karakteristik fisik yang dapat dilihat orang dalam diri influencer tersebut. Penelitian yang dilakukan oleh Sarashadi dan Dewi (2018) mendapat hasil bahwa sumber daya tarik vlogger berpengaruh positif pada sikap konsumen terhadap iklan.

Hasil penelitian oleh Irpansyah et al., (2019) mendapat hasil bahwa adanya pengaruh yang positif dan signifikan antara credibility seorang selebgram terhadap minat beli konsumen. Hasil penelitian oleh Hikmawati (2018) mengemukakan bahwa kredibilitas dan daya tarik pada celebrity endorser secara simultan berpengaruh positif terhadap minat beli konsumen. Berdasarkan teori dan dukungan riset terdahulu yang relevan, maka diajukan hipotesis sebagai berikut:

$\mathrm{H}_{1}$ : Daya Tarik (Attractiveness) Influencer Berpengaruh Positif pada Sikap Konsumen terhadap Iklan

\subsubsection{Pengaruh Positif Kepercayaan (Trustworthiness) Influencer pada Sikap Konsumen terhadap Iklan}

Menurut Shimp (2014) trustworthiness dikenal sebagai pribadi yang informasinya dapat dipercaya dan secara konsisten memberikan apa yang telah dijanjikan. Hasil penelitian oleh Sarashadi dan Dewi (2018) mendapat hasil bahwa sumber kepercayaan terhadap vlogger berpengaruh positif pada sikap konsumen terhadap iklan. Hasil penelitian oleh Irpansyah et al., (2019) mengemukakan bahwa adanya pengaruh yang positif dan signifikan antara power seorang selebgram terhadap minat beli produk mode lokal di Instagram. Berdasarkan teori dan dukungan riset terdahulu yang relevan, maka diajukan hipotesis sebagai berikut:

$\mathrm{H}_{2}$ : Kepercayaan (Trustworthiness) Influencer Berpengaruh Positif pada Sikap Konsumen terhadap Iklan

\subsubsection{Pengaruh Positif Keahlian (Expertise) Influencer pada Sikap Konsumen} terhadap Iklan

Menurut Shimp (2007) expertise (keahlian) adalah kemampuan influencer iklan untuk menarik konsumen agar membeli produk. Hasil penelitian oleh Sarashadi dan Dewi (2018) mendapat hasil bahwa sumber keahlian vlogger berpengaruh positif pada sikap konsumen terhadap iklan. Hasil penelitian oleh Ridha et al., (2018) mendapat hasil bahwa keahlian daripada artis yang menjadi endorser mempengaruhi minat beli konsumen. Berdasarkan teori dan dukungan riset terdahulu yang relevan, maka diajukan hipotesis sebagai berikut: 
$\mathrm{H}_{3}$ : Keahlian (Expertise) Influencer Berpengaruh Positif pada Sikap Konsumen terhadap Iklan

\subsubsection{Pengaruh Positif Sikap Konsumen terhadap Iklan pada Minat Beli}

Menurut Kotler dan Amstrong (2016) gaya hidup seseorang dilihat dari bagaimana dia berperilaku untuk mendapatkan atau mempergunakan barang-barang dan jasa, termasuk di dalamnya proses pengambilan keputusan pada penentuan kegiatan-kegiatan tersebut. Iklan merupakan salah satu alat yang penting dalam menjual nama atau merek suatu produk ke konsumen. Hasil penelitian oleh Sarashadi dan Dewi (2018) mendapat hasil bahwa sikap terhadap iklan berpengaruh secara positif pada niat beli. Hasil penelitian oleh Rahmah (2015) mengemukakan bahwa sikap terhadap iklan Sensodyne berpengaruh positif dan signifikan pada sikap konsumen terhadap produk. Berdasarkan teori dan dukungan riset terdahulu yang relevan, maka diajukan hipotesis sebagai berikut:

$\mathrm{H}_{4}$ : Sikap Konsumen terhadap Iklan Berpengaruh Positif pada Minat Beli

\subsubsection{Pengaruh Positif Daya Tarik Influencer pada Minat Beli melalui Sikap Konsumen terhadap Iklan}

Menurut Shimp (2014) terdapat salah satu komponen kredibilitas yaitu attractiveness (daya tarik) mengacu pada sejumlah karakteristik fisik yang dapat dilihat orang dalam diri influencer tersebut. Menurut Kotler dan Amstrong (2016) sikap terhadap iklan adalah tanggapan terhadap objek yang disiapkan oleh jiwa dan pikiran yang diorganisasikan melalui pengalaman dan mempengaruhi perilaku secara langsung. Menurut Kotler dan Keller (2016) minat beli konsumen adalah perilaku konsumen dimana konsumen memiliki keinginan dalam memilih dan mengkonsumsi suatu produk.

$\mathrm{H}_{5}$ : Daya Tarik Influencer Berpengaruh Positif pada Minat Beli melalui Sikap Konsumen terhadap Iklan

\subsubsection{Pengaruh Positif Kepercayaan Influencer pada Minat Beli melalui Sikap Konsumen terhadap Iklan}

Menurut Shimp (2014) trustworthiness (kepercayaan) dikenal sebagai pribadi yang informasinya dapat dipercaya. Kepercayaan sebagai konsisten memberikan apa yang telah dijanjikan. Menurut Kotler dan Amstrong (2016) sikap terhadap iklan adalah tanggapan terhadap objek yang disiapkan oleh jiwa dan pikiran yang diorganisasikan melalui pengalaman dan mempengaruhi perilaku secara langsung. Menurut Kotler dan Keller (2016), minat beli konsumen adalah perilaku konsumen dimana konsumen memiliki keinginan dalam memilih dan mengkonsumsi suatu produk.

$\mathrm{H}_{6}$ : Kepercayaan Influencer Berpengaruh Positif pada Minat Beli melalui Sikap Konsumen terhadap Iklan

\subsubsection{Pengaruh Positif Keahlian Influencer pada Minat Beli melalui Sikap terhadap} Iklan

Menurut Shimp (2007) expertise (keahlian) didefinisikan sebagai kemampuan influencer iklan untuk menarik konsumen agar membeli produk. Menurut Kotler dan Amstrong (2016) sikap terhadap iklan adalah tanggapan terhadap objek yang disiapkan oleh jiwa dan pikiran yang diorganisasikan melalui pengalaman dan mempengaruhi perilaku secara langsung. Menurut Kotler dan Keller (2016) minat beli konsumen adalah perilaku konsumen dimana konsumen memiliki keinginan dalam memilih dan mengkonsumsi suatu produk.

$\mathrm{H}_{7}$ : Keahlian Influencer Berpengaruh Positif pada Minat Beli melalui Sikap 


\section{Konsumen terhadap Iklan}

\subsection{Model Penelitian}

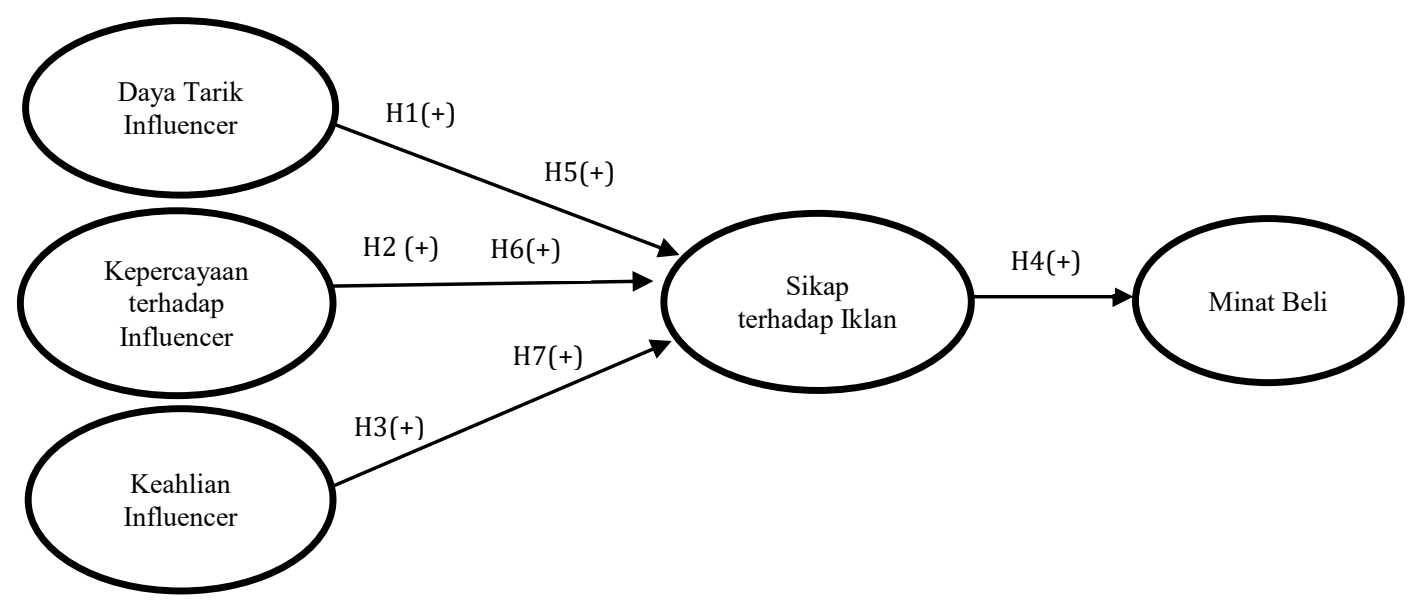

Gambar 1. Model Penelitian

\section{Metode Penelitian}

\subsection{Sampel dan Teknik Pengambilan Sampel}

Teknik pengambilan sampel (sampling) adalah proses untuk memilih jumlah elemen yang cukup dari populasi. Kondisi ini dimana populasi belum diketahui dari penelitian ini yang kemudian menyebabkan sulitnya untuk menentukan jumlah sampel yang sesuai (Sekaran dan Bougie, 2017). Ada dua jenis desain sampel, probability dan non probability sampling. Teknik pengambilan sampel yang digunakan dalam penelitian ini adalah metode non probability sampling dengan penentuan sampel menggunakan purposive sampling, yaitu teknik penentuan sampel dimana peneliti memilih sampel berdasarkan penilaian terhadap beberapa karakteristik anggota sampel yang disesuaikan dengan maksud penelitian. Adapun beberapa kriteria responden dalam penelitian ini adalah:

a. Followers (pengikut) pada media sosial Instagram milik Ayudia Bing Slamet khususnya Mahasiswa.

b. Mahasiswa Daerah Istimewa Yogyakarta yang pernah melihat atau stalking akun Instagram Ayudia Bing Slamet.

Ukuran sampel pada penelitian ini adalah sebanyak 200 responden. Penentuan jumlah sampel dalam penelitian ini disesuaikan dengan metode analisis yang digunakan yaitu Structural Equation Model (SEM). Menurut Ghozali (2017) dalam pengujian menggunakan metode analisis SEM, penentuan sampel dengan Teknik Maximum Likehood Estimation (MLE) yang menyebutkan bahwa jumlah sampel yang baik menurut MLE adalah berkisar 100-200 sampel, sehingga disarankan ukuran sampel adalah minimum sebanyak 5 sampai dengan 10 untuk setiap indikator. Dengan demikian bila indikator berjumlah 14, maka jumlah sampel minimum adalah 100. Maka dari itu diperoleh perhitungan sebagai berikut:

\section{Sampel = Jumlah Indikator x $8=21$ x $8=168$}

Berdasarkan perhitungan di atas dalam penelitian ini akan menggunakan 168 sampel responden, dengan menambahkan 2 responden, jadi jumlah sampel yang akan digunakan dalam penelitian ini minimal 170 responden.

\subsection{Teknik Pengumpulan Data}

Teknik pengumpulan data merupakan langkah yang paling strategis di dalam penelitian, karena tujuan utama dari penelitian adalah mendapatkan data. Teknik 
pengumpulan data dari penelitian ini dengan cara menyebarkan kuesioner. Menurut Sekaran dan Bougie (2017) kuesioner adalah pertanyaan tertulis yang memiliki beberapa alternatif jawaban dengan memilih dari alternatif jawaban tersebut. Kuesioner yang berupa Google Form dibagikan kepada responden yang mengikuti akun Instagram Ayudia Bing Slamet, yang berada di Daerah Istimewa Yogyakarta.

Skala yang digunakan dalam penelitian ini adalah skala likert. Menurut Sekaran dan Bougie (2017) skala likert adalah suatu skala yang dirancang untuk menelaah seberapa kuat subyek untuk menyetujui suatu pernyataan atau pertanyaan. Dalam penelitian, fenomena sosial ini telah ditetapkan secara spesifik oleh peneliti, yang selanjutnya disebut sebagai variabel penelitian.

Dengan skala likert, maka variabel yang akan diukur dijabarkan menjadi indikator variabel. Kemudian indikator tersebut dijadikan sebagai tolak ukur untuk menyusun itemitem dalam instrumen yang dapat berupa pernyataan atau pertanyaan dengan 5 poin untuk masing-masing pernyataan dan pertanyaan. Jawaban setiap instrumen yang menggunakan skala likert mempunyai gradasi dari segi positif sampai sangat negatif. Pada skala ini peneliti memberikan nilai atau skor pada setiap respon jawaban dapat dilihat pada tabel berikut:

Tabel 1. Skala Likert

\begin{tabular}{cc}
\hline Kategori & Skor/Nilai \\
\hline Sangat Setuju & 5 \\
Setuju & 4 \\
Netral & 3 \\
Tidak Setuju & 2 \\
Sangat Tidak Setuju & 1 \\
\hline
\end{tabular}

\subsection{Uji Kualitas Instrumen}

Uji kualitas instrumen adalah uji yang digunakan untuk menguji kualitas data dari angket. Penelitian ini menggunakam metode penelitian kuanitatif, kualitas instrumen penelitian berkenaan dengan validitas dan reliabilitas instrumen dan kualitas pengumpulan data berkenaan ketepatan cara-cara yang digunakan untuk mengumpulkan data. Uji kualitas instrumen berisi uji validitas dan uji reabilitas. Dari kedua uji tersebut hasil yang didapat belum tentu dapat menghasilkan data yang valid dan reliabel. Apabila instrumen tersebut tidak digunakan secara tepat dalam pengumpulan datanya (Sugiyono, 2015). Sekaran dan Bougie (2017) mengatakan alat riset yang baik sebaiknya mempunyai validitas dan realibilitas sebagai ketentuan yang krusial. Dan hasil penelitian dapat dipertanggungjawabkan secara ilmiah, maka informasi yang menyangkut validitas dan reliabilitas sebagai alat pengukur harus disampaikan.

\subsubsection{Uji Validitas}

Menurut Sekaran dan Bougie (2017) uji validitas merupakan teknik pengukuran kuesioner yang akan digunakan untuk meneliti valid atau tidak valid. Uji validitas ini mengukur setiap butir pertanyaan dalam kuesioner yang akan disebar peneliti untuk mengetahui apakah pertanyaannya valid atau tidak valid. Pengujian validitas dalam penelitian ini menggunakan alat CFA (Confimatory Factor Analisys) yang merupakan bagian dari AMOS. Menurut Ghozali (2017) valid atau tidak valid dapat dilihat dari nilai loading factor apabila nilai dari masing-masing butir pertanyaan lebih dari $>0,5$ dapat dikatakan valid akan tetapi jika $<0,5$ hasilnya tidak valid.

\subsubsection{Uji Reliabilitas}

Uji reliabilitas merupakan pengujian yang menunjukkan sejauh mana pengukuran suatu variabel tanpa menghasilkan bias (tanpa kesalahan), pengujian tersebut diperlukan untuk mengukur konsistensi menggunakan instrumen penelitian 
(Sekaran dan Bougie, 2017). Hasil yang dipreroleh kemudian akan dibandingkan dengan pertanyaan lain. Adapun kriteria yang digunakan pada pengujian reliabilitas yaitu Construct Reliability (CR), instrumen penelitian dapat dikatakan reliabel jika nilai CR > 0,7 atau masih berada dalam rentang 0,6 - 0,7 (Ghozali, 2017).

\subsection{Analisis Data dan Uji Hipotesis}

Analisis data untuk jenis penelitian yang digunakan dalam penelitian ini adalah penelitian kuantitatif dengan pendekatan deskriptif, Structural Equation Model (SEM) dengan program AMOS. SEM merupakan model penelitian yang memungkinkan seorang peneliti untuk mengukur indikator apa saja yang digunakan pada untuk identifikasi antar faktor dari sebuah konsep dan mengukur pengaruh atau hubungan antara faktor yang telah diidentifikasikan dimensinya. Menurut Ghozali (2017) bahwa dalam SEM memerlukan tujuh tahapan dalam pengujian hipotesis penelitian dan analisis data hingga sampai pada hasil yang diinginkan.

\section{Hasil Penelitian dan Pembahasan}

\subsection{Deskripsi Responden}

Untuk mengetahui karakteristik responden pada penelitian ini digunakan analisis persentase. Ringkasan hasil analisis deskriptif statistik yang telah dilakukan adalah sebagai berikut:

\subsubsection{Distribusi Responden Berdasarkan Usia}

Berdasarkan data primer yang telah diolah, hasil persebaran responden berdasarkan usia pada penelitian ini dapat dilihat pada tabel di bawah ini:

Tabel 2. Distribusi Responden Berdasarkan Usia

\begin{tabular}{ccc}
\hline Usia & Jumlah & $\begin{array}{c}\text { Persentase } \\
\mathbf{( \% )}\end{array}$ \\
\hline$<20$ tahun & 25 & $12,5 \%$ \\
$>20$ tahun & 175 & $87,5 \%$ \\
Total & 200 & $100 \%$ \\
\hline
\end{tabular}

Tabel 2 menunjukkan bahwa hasil dari analisa responden berdasarkan usia dengan rincian usia $>20$ Tahun 25 responden $(12,5 \%)$ dan $>20$ tahun 175 responden $(87,5 \%)$.

\subsubsection{Distribusi Responden Berdasarkan Jenis Kelamin}

Berdasarkan data primer yang telah diolah, hasil persebaran responden berdasarkan jenis kelamin pada penelitian ini dapat dilihat pada tabel di bawah ini:

Tabel 3. Distribusi Responden Berdasarkan Jenis Kelamin

\begin{tabular}{ccc}
\hline $\begin{array}{c}\text { Jenis } \\
\text { Kelamin }\end{array}$ & Jumlah & $\begin{array}{c}\text { Persentase } \\
\text { (\%) }\end{array}$ \\
\hline Laki-Laki & 42 & $21 \%$ \\
Perempuan & 158 & $79 \%$ \\
Total & 200 & $100 \%$ \\
\hline
\end{tabular}

Tabel 3 di atas menunjukkan bahwa responden dengan jenis kelamin laki-laki sebanyak 42 orang (21\%) dan responden dengan jenis kelamin perempuan sebanyak 158 orang $(79 \%)$. Hal ini menunjukkan bahwa mayoritas yang menjadi responden 
berjenis kelamin perempuan (79\%).

\subsubsection{Distribusi Responden Berdasarkan yang Pernah Stalk atau Mengikuti (Follow) Instagram Ayudia Bing Slamet}

Berdasarkan data primer yang telah diolah, maka hasil persebaran responden berdasarkan yang pernah stalk atau mengikuti (follow) Instagram Ayudia Bing Slamet (@ayudiac) pada penelitian ini dapat dilihat pada tabel di bawah ini:

\begin{tabular}{ccc}
$\begin{array}{c}\text { Tabel 4. Distribusi Responden Berdasarkan } \\
\text { Follow / Non } \\
\text { Follower }\end{array}$ & Jumlah & $\begin{array}{c}\text { Persentase } \\
\text { (\%) }\end{array}$ \\
\hline $\begin{array}{c}\text { Follower } \\
\text { Non }\end{array}$ & 160 & $80 \%$ \\
Followers & 40 & $20 \%$ \\
Total & 200 & $100 \%$ \\
\hline
\end{tabular}

Berdasarkan tabel 4 yang berisi data usia dapat dilihat bahwa hasil dari total 200 responden. Terdapat analisa responden adalah responden dengan mengikuti Instragram Ayudia 160 responden (80\%) dan tidak mengikuti tetapi pernah stalk 40 responden $(20 \%)$.

\subsection{Uji Kualitas Instrumen}

Uji kualitas instrumen bertujuan untuk menguji seberapa layak data untuk dapat dipercaya. Uji instrumen terdiri dari uji validitas dan reliabilitas dimana kedua uji ini digunakan untuk menguji kelayakan dari data penelitian.

\subsubsection{Uji Validitas}

Uji validitas adalah uji untuk mengukur kevalidan data kuesoner yang telah diisi oleh responden. Data dikatakan valid apabila data atau hasil uji validitas memiliki nilai variabel $\geq 0,5$. Apabila suatu nilai variabel di bawah dari 0,5 , maka data dikatakan tidak valid atau data tersebut harus didrop. Berikut ini adalah hasil dari uji validitas dengan menggunakan AMOS 24. 
Tabel 5. Hasil Uji Validitas

\begin{tabular}{|c|c|c|c|c|}
\hline Variabel & Indikator & $\begin{array}{c}\text { Factor } \\
\text { Loading }\end{array}$ & Batas & Ket. \\
\hline \multirow[t]{5}{*}{ Daya Tarik } & $\mathrm{X} 1.1$ & 0,57 & & Valid \\
\hline & $\mathrm{X} 1.2$ & 0,69 & & Valid \\
\hline & $\mathrm{X} 1.3$ & 0,56 & & Valid \\
\hline & $\mathrm{X} 1.4$ & 0,56 & & Valid \\
\hline & X1.5 & 0,58 & & Valid \\
\hline \multirow[t]{5}{*}{ Kepercayaan } & $\mathrm{X} 2.1$ & 0,63 & & Valid \\
\hline & $\mathrm{X} 2.2$ & 0,64 & & Valid \\
\hline & $\mathrm{X} 2.3$ & 0,58 & & Valid \\
\hline & $\mathrm{X} 2.4$ & 0,73 & & Valid \\
\hline & X2.5 & 0,71 & & Valid \\
\hline \multirow[t]{6}{*}{ Keahlian } & X3.1 & 0,87 & & Valid \\
\hline & X3.2 & 0,64 & & Valid \\
\hline & X3.3 & 0,84 & 0,5 & Valid \\
\hline & X3.4 & 0,72 & & Valid \\
\hline & X3.5 & 0,57 & & Valid \\
\hline & X3.6 & 0,50 & & Valid \\
\hline \multirow[t]{4}{*}{ Iklan } & Y1.1 & 0,67 & & Valid \\
\hline & Y1.2 & 0,56 & & Valid \\
\hline & Y1.3 & 0,69 & & Valid \\
\hline & Y1.4 & 0,57 & & Valid \\
\hline \multirow[t]{5}{*}{ Minat Beli } & Y2.1 & 0,53 & & Valid \\
\hline & Y2.2 & 0,59 & & Valid \\
\hline & Y2.3 & 0,59 & & Valid \\
\hline & Y2.4 & 0,55 & & Valid \\
\hline & Y2.5 & 0,56 & & Valid \\
\hline
\end{tabular}

Tabel 5 di atas menunjukkan nilai dari factor loading dengan batas dari nilai uji validitas $\geq 0,5$, maka dapat dikatakan seluruh variabel dalam penelitian ini valid.

\subsubsection{Uji Reliabilitas}

Uji reliabilitas menunjukkan kehandalan suatu alat ukur. Pengujian reliabilitas dalam penelitian ini menggunakan CR (construct reliability), dimana memiliki kriteria jika nilai CR > 0,7 maka variabel dapat dikatakan reliabel.

\section{Tabel 6. Hasil Uji Reliabilitas}

\begin{tabular}{cccc}
\hline Variabel & {$[\mathbf{\Sigma} \lambda \mathbf{i}]^{\mathbf{2}}$} & $\boldsymbol{\Sigma} \boldsymbol{\varepsilon i}$ & $\begin{array}{c}\text { Construct } \\
\text { Reability }\end{array}$ \\
\hline $\mathrm{X} 1$ & 8,88 & 3,13 & 0,85 \\
$\mathrm{X} 2$ & 10,87 & 1,76 & 0,88 \\
$\mathrm{X} 3$ & 13,50 & 2,66 & 0,98 \\
Y1 & 7,06 & 1,76 & 0,75 \\
Y2 & 12,54 & 2,15 & 0,87 \\
\hline
\end{tabular}

Ghozali (2017) menyatakan bahwa hasil pengujian dikatakan reliabel jika memiliki nilai construct reliability $>0,7$. Hasil pengujian yang disajikan dalam tabel 6 menunjukkan bahwa nilai CR pada 5 variabel penelitian masing-masing nilainya lebih besar dari 0,7. Berdasarkan hasil tersebut maka dapat disumpulkan bahwa keseluruhan 
instrumen penelitian tersebut reliabel sehingga dapat digunakan dalam penelitian ini.

\subsection{Uji Analisis Data}

Sesuai dengan model yang dikembangkan pada penelitian ini, maka alat analisis data yang digunakan adalah SEM yang dioperasikan dengan menggunakan aplikasi AMOS. Langkah-langkah tersebut mengacu pada proses analisis SEM menurut Ghozali (2017). Adapun urutan langkah-langkah analisis tersebut meliputi:

\subsubsection{Pembahasan Model Berdasarkan}

Pemodelan SEM yang terdapat pada penelitian ini telah didasari oleh teori yang kuat dan telah dikonfirmasi oleh beberapa penelitian terdahulu seperti yang sudah dijelaskan pada metode penelitian di atas. Seperti yang disampaikan oleh Ghozali (2017) bahwa hubungan kausalitas antar variabel yang diasumsi oleh peneliti bukan senantiasa hanya didasari dari metode analisis yang dipilih tetapi juga harus didasari oleh teori yang kuat karena tanpa landasan tersebut, SEM tidak akan dapat digunakan.

\subsubsection{Menyusun Diagram Alur (Path Diagram)}

Setelah pengembangan model berbasis teori, maka langkah selanjutnya yaitu menyusun model tersebut dalam bentuk diagram alur yang akan memudahkan untuk melihat hubungan kausalitas yang akan diuji. Dalam diagram alur, hubungan antara konstruk akan dinyatakan melalui anak panah. Anak panah yang lurus menunjukkan hubungan kausal yang langsung antara konstruksi dengan konstruksi yang lainnya. Pengukuran hubungan antar variabel menggunakan SEM. Berdasarkan landasan teori yang ada maka dibuat diagram jalur untuk SEM sebagai berikut:

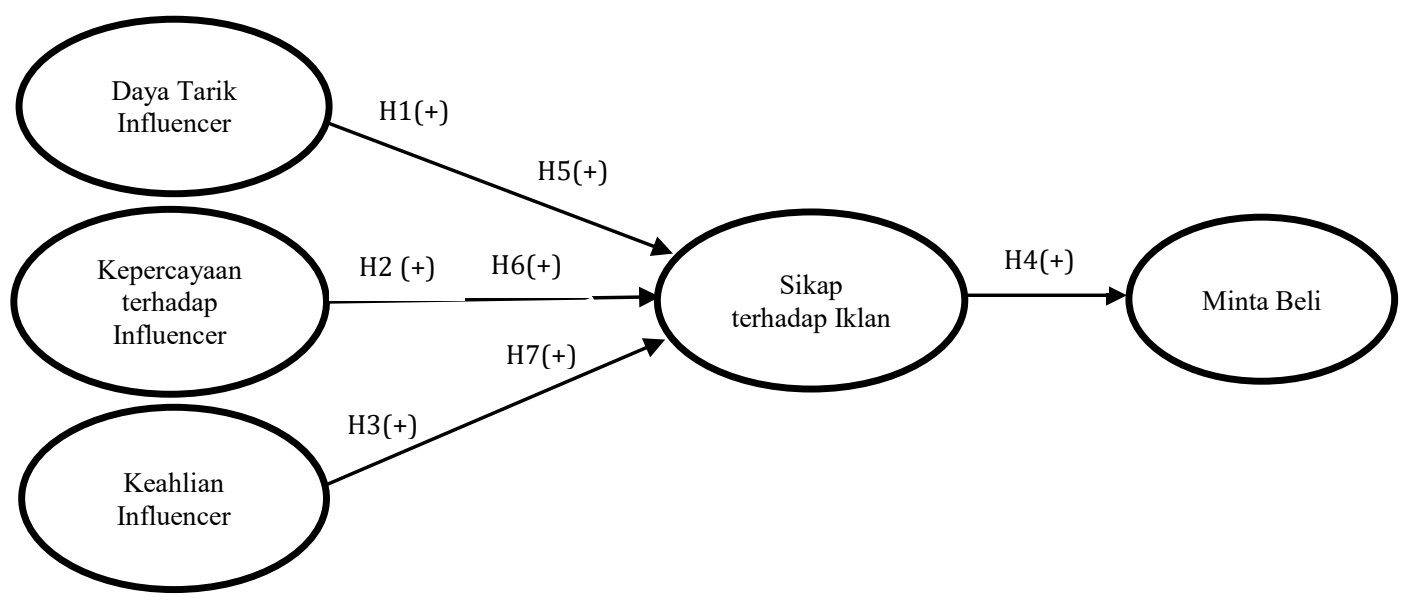

Gambar 2. Diagram Alur

\subsubsection{Konversi Diagram Alur ke Dalam Persamaan Struktural}

Uji model measurement adalah untuk menguji hubungan antara variabel dependen (eksogen) dengan variabel independen (endogen). Digabungkannya pengujian model struktural dan pengukuran tersebut memungkinkan peneliti untuk menguji measurement error sebagai bagian yang tidak terpisahkan dari SEM serta melakukan analisis faktor bersamaan dengan pengujian hipotesis (Bollen, 2018). Pada uji measurement model diperoleh hasil chi-square sebesar 374,519, degrees of freedom sebesar 200 dan probability level sebesar 0,000. 


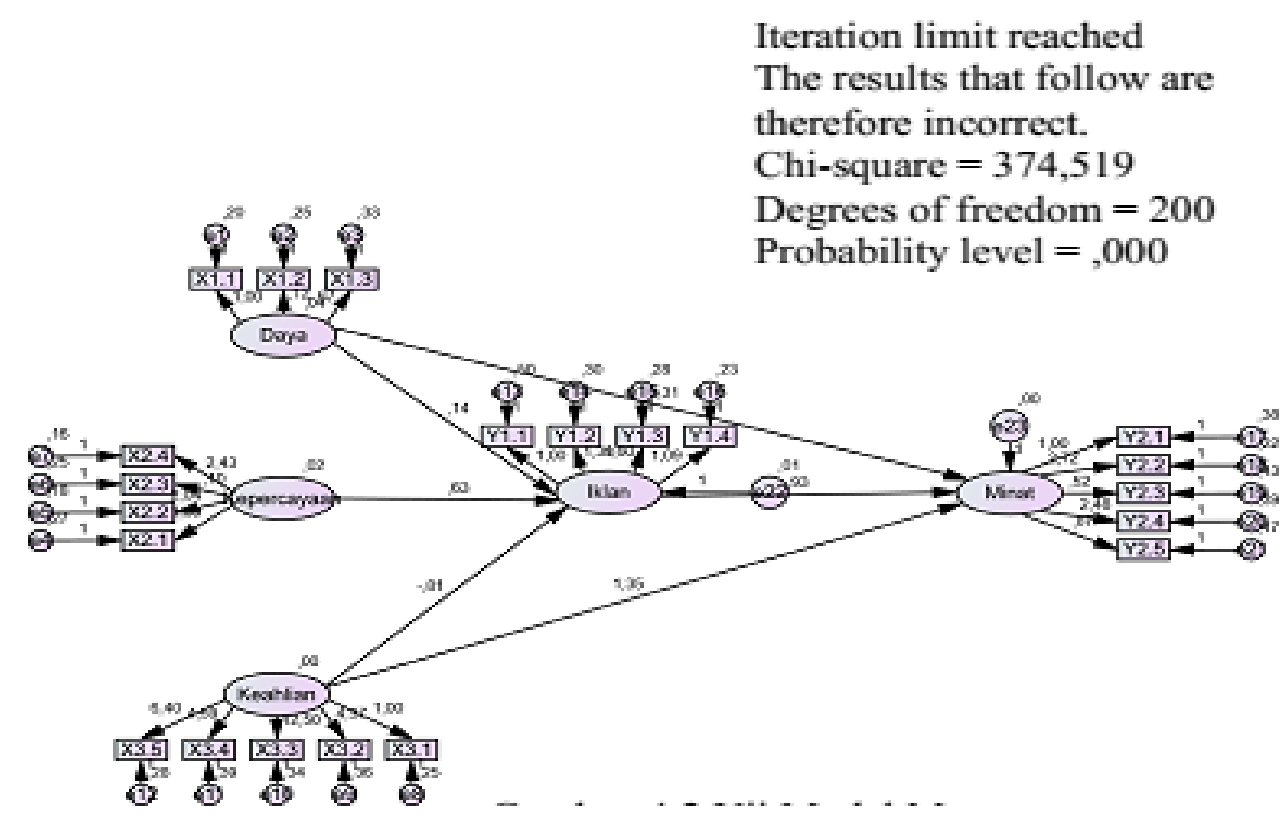

Gambar 3. Uji Measurement Model

Gambar 3 menjelaskan hasil dari nilai chi-square yang besar dikarenakan jumlah degrees of freedom yang cukup besar yaitu 200. Apabila nilai degrees of freedom besar, maka akan berpengaruh pada nilai chi-square.

\subsubsection{Input Matriks dan Estimasi Model}

Input matriks yang digunakan adalah kovarian dan korelasi. Estimasi model yang digunakan adalah estimasi Maximum Likelihood (ML). Estimasi ML telah dipenuhi dengan asumsi sebagai berikut:

\subsubsection{Ukuran Sampel}

Penelitian ini menggunakan sampel sebanyak 200 responden. Jika mengacu pada ketentuan yang berpendapat bahwa jumlah sampel yang representatif adalah sekitar 100-200 (Ghozali, 2017). Maka, ukuran sampel yang digunakan dalam penelitian ini telah memenuhi asumsi yang diperlukan uji SEM.

\subsubsection{Uji Normalitas}

Uji normalitas dilakukan dengan menggunakan z value (critical ratio atau CR pada output AMOS 24) dari nilai skewness dan kurtosis sebaran data. Uji normalitas bertujuan untuk melihat bagaimana data berdistribusi secara normal. Untuk mengetahui hasil dari uji normalitas dapat dilihat dari nilai critical ratio skewness value dengan nilai $\pm 2,58$. Apabila critical ratio skewness value di bawah $\pm 2,58$ maka data dikatakan normal (Ghozali, 2017). Berikut adalah hasil dari uji normalitas: 
Tabel 7. Hasil Uji Normalitas

\begin{tabular}{lcclrrr}
\hline Variabel & Min & Max & Skew & C.R. & Kurtosis & \multicolumn{1}{c}{ C.R. } \\
\hline Y2.5 & 1,000 & 5,000 &,- 573 & $-2,311$ &, 016 &, 046 \\
Y2.4 & 2,000 & 5,000 &,- 861 & $-2,473$ &, 354 & 1,020 \\
Y2.3 & 1,000 & 5,000 &,- 761 & $-2,394$ &, 456 & 1,317 \\
Y2.2 & 1,000 & 5,000 &,- 938 & $-2,413$ & 1,323 & 2,818 \\
Y2.1 & 2,000 & 5,000 & $-1,041$ & $-2,013$ &, 184 &, 532 \\
Y1.4 & 2,000 & 5,000 & $-1,085$ & $-2,262$ &, 623 & 1,797 \\
Y1.3 & 2,000 & 5,000 & $-1,106$ & $-2,384$ &, 669 & 1,931 \\
Y1.2 & 2,000 & 5,000 &,- 294 & $-1,699$ &,- 388 & $-1,121$ \\
Y1.1 & 1,000 & 5,000 &,- 487 & $-2,412$ &,- 458 & $-1,323$ \\
X3.5 & 2,000 & 5,000 &,- 705 & $-1,070$ &, 877 & 2,532 \\
X3.4 & 1,000 & 5,000 &,- 523 & $-2,018$ &,- 382 & $-1,102$ \\
X3.3 & 1,000 & 5,000 &,- 523 & $-1,019$ &,- 426 & $-1,230$ \\
X3.2 & 1,000 & 5,000 &,- 522 & $-1,016$ &,- 166 &,- 481 \\
X3.1 & 3,000 & 5,000 &,- 334 & $-1,926$ &,- 761 & $-2,196$ \\
X2.4 & 3,000 & 5,000 &,- 413 & $-2,382$ &,- 810 & $-2,337$ \\
X2.3 & 3,000 & 5,000 &,- 227 & $-1,312$ &,- 937 & $-2,506$ \\
X2.2 & 2,000 & 5,000 &,- 772 & $-1,454$ &, 074 &, 214 \\
X2.1 & 2,000 & 5,000 &,- 468 & $-1,704$ &,- 638 & $-1,842$ \\
X1.3 & 2,000 & 5,000 &,- 645 & $-2,224$ &, 621 & 1,794 \\
X1.2 & 3,000 & 5,000 &,- 587 & $-2,390$ &,- 714 & $-2,063$ \\
X1.1 & 3,000 & 5,000 &,- 735 & $-2,245$ &,- 482 & $-1,391$ \\
Multivariate & & & & & 83,427 & 18,980 \\
\hline
\end{tabular}

Tabel 7 menunjukkan hasil uji normalitas secara univariate mayoritas berdistribusi normal karena nilai critical ratio skewness value di bawah $\pm 2,58$, maka hasil dapat disimpulkan bahwa data terdistribusi secara normal.

\subsubsection{Identifikasi Outliers}

Evaluasi terhadap multivariate outliers dapat dilihat melalui output AMOS mahalanobis distance. Kriteria yang digunakan pada tingkat $\mathrm{p}<0,001$. Jarak tersebut dievaluasi dengan menggunakan $\mathrm{X}^{2}$ pada derajat bebas sebesar jumlah variabel terukur yang digunakan dalam penelitian. Dalam kasus ini variabelnya adalah terukur yang digunakan dalam penelitian.

Hasil dalam uji outlier dapat dilihat dari data univariate outlier maupun multivariate outlier. Untuk melihat multivariate outlier dilakukan dengan melihat nilai malahanobis distance. Nilai dari malahanobis distance yang telah diuji di AMOS 24 akan dibandingkan dengan nilai chi-square. Berdasarkan ketentuan tersebut, pada penelitian ini nilai chi-square diperoleh 374,519 dan nilai terbesar pada malahanobis distance 78,469. Oleh karena itu dapat disimpulkan bahwa dalam penelitian ini tidak terdapat permasalahan multivariate outlier dalam penelitian ini.

\subsubsection{Identifikasi Model Struktral}

Beberapa cara untuk melihat ada tidaknya problem identifikasi adalah dengan melihat hasil estimasi. Analisis SEM hanya dapat dilakukan apabila hasil identifikasi model menunjukkan bahwa model termasuk dalam kategori over-identified. Identifikasi ini dilakukan dengan melihat nilai degree of freedom (df) dari model yang dibuat. 
Tabel 8. Notes For Model

\begin{tabular}{ll}
\hline $\begin{array}{l}\text { Number of distinct sample } \\
\text { moments }\end{array}$ & 250 \\
$\begin{array}{l}\text { Number of distinct parameters } \\
\text { to be estimated }\end{array}$ & 50 \\
\begin{tabular}{l} 
Degrees of freedom $(250-50)$ \\
\hline
\end{tabular} & 200 \\
\hline
\end{tabular}

Tabel 8 menunjukkan hasil output AMOS yang menunjukkan nilai $d f$ model sebesar 200. Hal ini mengindikasikan bahwa model termasuk kategori over identified karena memiliki nilai $d f$ positif. Oleh karena itu analisa data bisa dilanjutkan ke tahap selanjutnya.

\subsubsection{Menilai Kriteria Goodness of Fit}

Menilai goodness of fit menjadi tujuan utama dalam SEM untuk mengetahui sampai seberapa jauh model dihipotesiskan fit atau cocok dengan sampel data. Hasil goodness of fit ditampilkan pada data berikut ini:

Tabel 9. Menilai Goodness of Fit

\begin{tabular}{cccc}
\hline $\begin{array}{c}\text { Goodness of } \\
\text { Fit Index }\end{array}$ & $\begin{array}{c}\text { Nilai } \\
\text { Kritis }\end{array}$ & Hasil & $\begin{array}{c}\text { Evaluasi } \\
\text { Model }\end{array}$ \\
\hline Chi-Square & $\begin{array}{c}\text { Mendekati } \\
\text { Nol }\end{array}$ & 374,519 & Buruk \\
& & \\
$\begin{array}{c}\text { Probability } \\
\text { level }\end{array}$ & $\geq 0,05$ & 000 & Buruk \\
CMIN/DF & $<2,00$ & 2,021 & Buruk \\
CFI & $\geq 0,95$ & 0,975 & Baik \\
RMSEA & $\leq 0,08$ & 0,078 & Baik \\
TLI & $\geq 0,90$ & 0,901 & Baik \\
GFI & $\geq 0,90$ & 0.838 & Marjinal \\
AGFI & $\geq 0,90$ & 0.795 & Marjinal \\
\hline
\end{tabular}

Tabel 9 menunjukkan nilai chi-square pada penelitian ini sebesar 374,519. Probability menunjukkan hasil lebih kecil dari 0,05 yaitu 0,000. Hasil ini menunjukkan bahwa nilai chi-square dan nilai probability tidak sesuai dengan ketentuan, sehingga termasuk ke dalam kategori buruk (tidak cocok).

CMIN/DF merupakan indeks kesesuaian parsiomonious yang mengukur goodness of fit model dengan jumlah koefisien-koefisien estimasi yang diharapkan untuk mencapai kesesuaian. Hasil CMIN/DF pada penelitian ini 2,021 menunjukkan bahwa model penelitian buruk.

Goodnes of Fit Indeks (GFI) menunjukkan tingkat kesesuaian model secara keseluruhan yang dihitung dari residual kuadrat dari model yang diprediksi dibandingkan data sebenarnya. Nilai GFI pada model ini adalah 0,838 . Nilai mendekati dengan tingkat yang direkomendasikan $\geq 0,90$ menunjukkan model penelitian marginal fit (baik).

RMSEA adalah indeks yang digunakan untuk mengkompensasi nilai chi-square dalam sampel yang besar. Nilai RMSEA penelitian ini adalah 0,078 dengan nilai yang direkomendasikan yaitu $\leq 0,08$ hal ini menunjukkan model penelitian fit (baik).

AGFI adalah GFI yang disesuaikan dengan rasio antara $d f$ yang diusulkan dan $d f$ dari null model. Nilai AGFI pada model ini adalah 0,795. Nilai mendekati dengan tingkat yang direkomendasikan $\geq 0,90$ menunjukkan model penelitian marginal fit. 
TLI merupakan indeks kesesuaian yang kurang dipengaruhi ukuran sampel. Nilai TLI pada penelitian ini adalah 0,901 dengan nilai yang direkomendasikan yaitu $\geq 0,90$ hal ini menunjukkan model penelitian fit (baik).

CFI merupakan indeks yang relatif tidak sensitif terhadap besarnya sampel dan kerumitan model. Nilai CFI pada penelitian ini adalah 0,975 dengan nilai yang direkomendasikan yaitu $\geq 0,90$ hal ini menunjukkan model penelitian fit (baik).

Dalam penelitian SEM menggunakan AMOS peneliti tidak diwajibkan semua kriteria bernilai baik, menurut Haryono (2017) menyatakan bahwa minimal 3 nilai yang memenuhi kriteria goodness of fit. Berdasarkan keseluruhan pengukuran goodness of fit di atas mengindikasikan bahwa model yang diajukan dalam penelitian ini diterima.

\subsection{Uji Hipotesis}

Tabel 7. Hasil Uji Hipotesis

\begin{tabular}{|c|c|c|c|c|c|}
\hline Hipotesis & $\mathbf{H}$ & Estimate & S.E. & C.R. & Ket. \\
\hline $\begin{array}{l}\text { Daya Tarik } \rightarrow \text { Sikap } \\
\text { terhadap Iklan }\end{array}$ & H1 & 0,13 & 0,29 & 0,00 & $\begin{array}{c}\text { Positif } \\
\text { Signifikan }\end{array}$ \\
\hline $\begin{array}{l}\text { Kepercayaan } \rightarrow \\
\text { Sikap terhadap Iklan }\end{array}$ & $\mathrm{H} 2$ & 0,63 & 0,52 & 0,00 & $\begin{array}{c}\text { Positif } \\
\text { Signifikan }\end{array}$ \\
\hline $\begin{array}{c}\text { Keahlian } \rightarrow \text { Sikap } \\
\text { terhadap Iklan }\end{array}$ & H3 & 1,94 & 0,38 & 0,00 & $\begin{array}{l}\text { Positif } \\
\text { Signifikan }\end{array}$ \\
\hline $\begin{array}{l}\text { Sikap terhadap Iklan } \\
\rightarrow \text { Minat Beli }\end{array}$ & $\mathrm{H} 4$ & 0,93 & 0,94 & 0,98 & $\begin{array}{l}\text { Positif } \\
\text { Signifikan }\end{array}$ \\
\hline $\begin{array}{c}\text { Hipotesis } \\
\text { Daya Tarik } \rightarrow \text { Minat } \\
\text { Beli melalui Sikap } \\
\text { terhadap Iklan }\end{array}$ & H5 & $\begin{array}{c}\text { Direct } \\
3,93\end{array}$ & & $\begin{array}{c}\text { Indirect } \\
8,17\end{array}$ & $\begin{array}{c}\text { Ket. } \\
\text { Mampu } \\
\text { Memediasi }\end{array}$ \\
\hline $\begin{array}{c}\text { Kepercayaan } \rightarrow \\
\text { Minat Beli melalui } \\
\text { Sikap terhadap Iklan }\end{array}$ & H6 & 0,19 & & 0,36 & $\begin{array}{c}\text { Mampu } \\
\text { Memediasi }\end{array}$ \\
\hline $\begin{array}{c}\text { Keahlian } \rightarrow \text { Minat } \\
\text { Beli melalui Sikap } \\
\text { terhadap Iklan }\end{array}$ & H7 & 0,46 & & 0,54 & $\begin{array}{l}\text { Mampu } \\
\text { Memediasi }\end{array}$ \\
\hline
\end{tabular}

\subsection{Pembahasan}

\subsubsection{Daya Tarik Influencer Berpengaruh Positif pada Sikap Konsumen terhadap Iklan}

Hasil penelitian ini menunjukkan bahwa daya tarik influencer berpengaruh positif pada sikap konsumen terhadap iklan, dimana ketika influencer mampu mempromosikan produk dengan daya tarik yang baik, maka dapat mempengaruhi sikap konsumen terhadap iklan. Hal ini juga telah dibuktikan dengan hasil penelitian bahwa daya tarik influencer berpengaruh positif dan signifikan terhadap sikap konsumen terhadap iklan dengan nilai probabilitas 0,007 , yaitu di bawah nilai 
penerimaan sebesar 0,05. Artinya, mahasiswa di Daerah Istimewa Yogyakarta merasa bahwa daya tarik influencer Ayudia Bing Slamet dapat mempengaruhi sikap konsumen terhadap iklan yang ditawarkan oleh Ayudia Bing Slamet. Hipotesis pertama yang mengatakan daya tarik influencer berpengaruh positif pada sikap konsumen terhadap iklan diterima.

Hasil penelitian ini sejalan dengan hasil penelitian terdahulu yang dilakukan oleh Sarashadi dan Dewi (2018) mendapat hasil bahwa sumber daya tarik vlogger berpengaruh positif pada sikap konsumen terhadap iklan. Hasil penelitian lainnya yang dilakukan oleh Irpansyah et al., (2019) mendapat hasil bahwa adanya pengaruh yang positif dan signifikan antara credibility seorang selebgram terhadap minat beli konsumen.

\subsubsection{Kepercayaan (Trustworthiness) terhadap Influencer Berpengaruh Positif pada Sikap Konsumen terhadap Iklan}

Hasil penelitian ini menunjukkan bahwa kepercayaan (trustworthiness) terhadap influencer berpengaruh positif pada sikap konsumen terhadap iklan, dimana ketika influencer menyampaikan pesan iklan dapat dipercaya dengan baik, maka dapat mempengaruhi sikap konsumen terhadap iklan. Hal ini juga telah dibuktikan dengan hasil penelitian bahwa kepercayaan (trustworthiness) berpengaruh positif dan signifikan terhadap sikap konsumen terhadap iklan dengan nilai probabilitas 0,008 yaitu di bawah nilai penerimaan sebesar 0,05. Artinya, mahasiswa di Daerah Istimewa Yogyakarta merasa bahwa kepercayaan (trustworthiness) dalam menyampaikan pesan iklan Ayudia Bing Slamet dapat mempengaruhi sikap konsumen terhadap iklan yang ditawarkan oleh Ayudia Bing Slamet. Hipotesis kedua yang mengatakan kepercayaan influencer berpengaruh positif pada sikap konsumen terhadap iklan diterima.

Hasil penelitian ini sejalan dengan hasil penelitian terdahulu yang dilakukan oleh Sarashadi dan Dewi (2018) mendapat hasil bahwa sumber kepercayaan terhadap vlogger berpengaruh positif pada sikap konsumen terhadap iklan. Hasil penelitian lainnya yang dilakukan oleh Irpansyah et al., (2019) mengemukakan bahwa adanya pengaruh yang positif dan signifikan antara power seorang selebgram terhadap minat beli produk mode lokal di Instagram.

\subsubsection{Keahlian (Expertise) Influencer Berpengaruh Positif pada Sikap Konsumen terhadap Iklan}

Hasil penelitian ini menunjukkan bahwa keahlian (expertise) influencer berpengaruh positif pada sikap konsumen terhadap iklan, dimana ketika influencer menyampaikan pesan iklan memiliki keahlian dengan baik, maka dapat mempengaruhi sikap konsumen terhadap iklan. Hal ini juga telah dibuktikan dengan hasil penelitian bahwa keahlian (expertise) berpengaruh positif dan signifikan terhadap sikap konsumen terhadap iklan dengan nilai probabilitas 0,000 yaitu di bawah nilai penerimaan sebesar 0,05. Artinya, mahasiswa di Daerah Istimewa Yogyakarta merasa bahwa keahlian (expertise) dalam menyampaikan pesan iklan Ayudia Bing Slamet dapat mempengaruhi sikap konsumen terhadap iklan yang ditawarkan oleh Ayudia Bing Slamet. Hipotesis ketiga yang mengatakan keahlian influencer berpengaruh positif pada sikap konsumen terhadap iklan diterima.

Hasil penelitian ini sejalan dengan hasil penelitian terdahulu yang dilakukan oleh Sarashadi dan Dewi (2018) mendapat hasil bahwa sumber keahlian vlogger berpengaruh positif pada sikap konsumen terhadap iklan. Hasil penelitian lainnya yang dilakukan oleh Ridha et al., (2018) mendapat hasil bahwa keahlian artis yang menjadi endorser mempengaruhi minat beli konsumen. 


\subsubsection{Sikap Konsumen terhadap iklan Berpengaruh Positif pada Minat Beli}

Hasil penelitian ini menunjukkan bahwa sikap terhadap iklan berpengaruh positif pada minat beli, yang dimana sikap terhadap iklan dapat mempengaruhi minat beli konsumen. Hal ini juga telah dibuktikan dengan hasil penelitian bahwa sikap terhadap iklan berpengaruh positif dan signifikan terhadap minat beli dengan nilai probabilitas 0,039 yaitu di bawah nilai penerimaan sebesar 0,05. Artinya, mahasiswa di Daerah Istimewa Yogyakarta merasa bahwa sikap konsumen terhadap iklan produk yang diiklankan Ayudia Bing Slamet dapat mempengaruhi minat beli konsumen. Hipotesis keempat yang mengatakan sikap konsumen terhadap iklan berpengaruh positif pada minat beli diterima.

Hasil penelitian ini sejalan dengan hasil penelitian terdahulu yang dilakukan oleh Sarashadi dan Dewi (2018) mendapat hasil bahwa sikap terhadap iklan berpengaruh secara positif pada niat beli. Hasil penelitian lainnya yang dilakukan oleh Rahmah (2015) mengemukakan bahwa sikap terhadap iklan Sensodyne berpengaruh positif dan signifikan pada sikap konsumen terhadap produk.

\subsubsection{Daya Tarik Influencer Berpengaruh Positif pada Minat Beli melalui Sikap Konsumen terhadap Iklan}

Berdasarkan dari hasil pengujian dinyatakan bahwa daya tarik influencer memiliki pengaruh positif dan signifikan terhadap minat beli melalui sikap terhadap iklan sebagai variabel mediasi dan dapat disimpulkan hipotesis kelima diterima karena adanya pengaruh hubungan antar variabel. Hal ini juga telah dibuktikan dengan hasil penelitian bahwa nilai direct effect yaitu 3,935 di bawah nilai indirect effect sebesar 8,178 .

Dengan demikian pengaruh daya tarik influencer terhadap minat beli lebih baik secara tidak langsung melalui sikap terhadap iklan yang berarti bahwa sikap terhadap iklan mahasiswa di Daerah Istimewa Yogyakarta mampu memediasi pengaruh daya tarik influencer terhadap minat beli konsumen. Sehingga dapat disimpulkan bahwa semakin menarik daya tarik influencer yang dilakukan oleh Ayudia saat mempromosikan produk akan berpengaruh terhadap minat beli melalui sikap terhadap iklan.

\subsubsection{Kepercayaan Influencer Berpengaruh Positif pada Minat Beli melalui Sikap Konsumen terhadap Iklan}

Berdasarkan dari hasil pengujian dinyatakan bahwa kepercayaan influencer memiliki pengaruh positif dan signifikan terhadap minat beli melalui sikap terhadap iklan sebagai variabel mediasi dan dapat disimpulkan hipotesis keenam diterima karena adanya pengaruh hubungan antar variabel. Hal ini juga telah dibuktikan dengan hasil penelitian bahwa nilai direct effect yaitu 0,195 di bawah nilai indirect effect sebesar 0,361 .

Dengan demikian pengaruh kepercayaan influencer terhadap minat beli lebih baik secara tidak langsung melalui sikap terhadap iklan yang berarti bahwa sikap terhadap iklan mahasiswa di Daerah Istimewa Yogyakarta mampu memediasi pengaruh kepercayaan influencer terhadap minat beli konsumen. Sehingga dapat disimpulkan bahwa semakin baik kepercayaan influencer yang dilakukan oleh Ayudia saat mempromosikan produk akan berpengaruh terhadap minat beli melalui sikap terhadap iklan. 


\subsubsection{Keahlian Influencer Berpengaruh Positif pada Minat Beli melalui Sikap Konsumen terhadap Iklan}

Berdasarkan dari hasil pengujian dinyatakan keahlian influencer memiliki pengaruh positif dan signifikan terhadap minat beli melalui sikap terhadap iklan sebagai variabel mediasi dan dapat disimpulkan hipotesis ketujuh diterima karena adanya pengaruh hubungan antar variabel. Hal ini juga telah dibuktikan dengan hasil penelitian bahwa nilai direct effect yaitu 0,461 di bawah nilai indirect effect sebesar 0,541 .

Dengan demikian pengaruh keahlian influencer terhadap minat beli lebih baik secara tidak langsung melalui sikap terhadap iklan yang berarti bahwa sikap terhadap iklan mahasiswa di Daerah Istimewa Yogyakarta mampu memediasi pengaruh daya tarik influencer terhadap minat beli konsumen. Sehingga dapat disimpulkan bahwa semakin menarik keahlian influencer yang dilakukan oleh Ayudia saat mempromosikan produk akan berpengaruh terhadap minat beli melalui sikap terhadap iklan.

\section{Kesimpulan dan Saran}

\subsection{Kesimpulan}

Berdasarkan penelitian yang telah dilakukan, maka terdapat beberapa kesimpulan:

1. Daya tarik influencer berpengaruh positif pada sikap konsumen terhadap iklan. Hal ini dibuktikan dengan nilai probabilitas 0,007 , yaitu di bawah nilai penerimaan sebesar 0,05 . Artinya, hipotesis pertama yang mengatakan daya tarik influencer berpengaruh positif pada sikap konsumen terhadap iklan diterima.

2. Kepercayaan (trustworthiness) influencer berpengaruh positif pada sikap konsumen terhadap iklan. Hal ini dibuktikan dengan nilai probabilitas 0,008, yaitu di bawah nilai penerimaan sebesar 0,05. Artinya, hipotesis kedua yang mengatakan kepercayaan influencer berpengaruh positif pada sikap konsumen terhadap iklan diterima.

3. Keahlian (expertise) influencer berpengaruh positif pada sikap konsumen terhadap iklan. Hal ini dibuktikan dengan nilai probabilitas 0,000 , yaitu di bawah nilai penerimaan sebesar 0,05. Artinya, hipotesis ketiga yang mengatakan keahlian influencer berpengaruh positif pada sikap konsumen terhadap iklan diterima.

4. Sikap konsumen terhadap iklan berpengaruh positif pada minat beli. Hal ini dibuktikan dengan nilai probabilitas 0,039 yaitu di bawah nilai penerimaan sebesar 0,05. Artinya, hipotesis keempat yang mengatakan sikap konsumen terhadap iklan berpengaruh positif pada minat beli diterima.

5. Daya tarik influencer berpengaruh positif pada minat beli melalui sikap konsumen terhadap iklan. Hal ini dibuktikan dengan nilai direct effect yaitu 3,935 di bawah nilai indirect effect sebesar 8,178. Artinya, hipotesis kelima yang mengatakan daya tarik influencer berpengaruh positif pada minat beli melalui sikap konsumen terhadap iklan diterima.

6. Kepercayaan influencer berpengaruh positif pada minat beli melalui sikap konsumen terhadap iklan. Hal ini dibuktikan dengan nilai direct effect yaitu 0,195 di bawah nilai indirect effect sebesar 0,361. Artinya, hipotesis keenam yang mengatakan kepercayaan influencer berpengaruh positif pada minat beli melalui sikap konsumen terhadap iklan diterima.

7. Keahlian influencer berpengaruh positif pada minat beli melalui sikap konsumen terhadap iklan. Hal ini dibuktikan dengan nilai direct effect yaitu 0,461 di bawah nilai indirect effect sebesar 0,541. Artinya, hipotesis ketujuh yang mengatakan keahlian influencer berpengaruh positif pada minat beli melalui sikap konsumen terhadap iklan diterima. 


\subsection{Saran}

Berdasarkan penelitian yang telah dilakukan, maka terdapat beberapa saran:

1. Akademik

a. Peneliti selanjutnya dapat menambah jumlah sampel yang diteliti agar bisa mendapatkan hasil penelitian yang lebih baik dan akurat.

b. Peneliti selanjutnya dapat memperluas ruang lingkup populasi.

c. Peneliti selanjutnya dapat menganalisis variabel bebas yang lainnya, agar nantinya dapat diketahui variabel apa saja yang dapat mempengaruhi variabel kredibilitas influencer dan minat beli.

2. Praktek

Dalam pengumpulan data, dapat menambahkan dengan metode wawancara atau observasi kepada responden agar hasilnya dapat lebih baik dan akurat.

\section{Daftar Pustaka}

Ghozali, Imam. (2017). Model Persamaan Struktural Konsep dan Aplikasi dengan Program AMOS 24. Universitas Diponegoro.

Hariyanti, N. T., \& Wirapraja, A. (2018). Marketing sebagai Strategi Pemasaran Digital Era Modern. Salemba.

Haryono, S. (2017). Metode SEM untuk Penelitian Manajemen AMOS Lisrel PLS. Luxima Metro Media.

Hikmawati, H. (2018). Pengaruh Atribut Kredibilitas dan Daya Tarik Beauty Vlogger Sebagai Celebrity Endorser terhadap Minat Beli Konsumen. Doctoral Dissertation, University of Muhammadiyah Malang.

Irpansyah, M. A., Ramdan, A. M., \& Danial, R. D. M. (2019). Kredibilitas dan Kekuatan Selebgram dalam Meningkatkan Minat Beli pada Toko Online di Instagram. COSTING: Journal of Economic, Business and Accounting, 2(2), 248-255.

Kotler, P., \& Amstrong, G. (2016). Dasar-Dasar Pemasaran. Erlangga.

Kotler, P., \& Keller, K. L. (2016). Manajemen Pemasaran. PT. Indeks.

Li, S., Walters, G., Packer, J., \& Scott, N. (2018). Using Skin Conductance and Facial Electromyography To Measure Emotional Responses To Tourism Advertising. Current Issues in Tourism, 21(15), 1761-1783.

Lim, X. J., Radzol, A. M., Cheah, J., \& Wong, M. W. (2017). The Impact of Social Media Influencers On Purchase Intention And The Mediation Effect of Customer Attitude. Asian Journal of Business Research, 7(2), 19-36.

Morissan. (2014). Komunikasi Pemasaran Terpadu. Kencana.

Ridha, A., Perdana, A. H., \& As' ad, A. (2018). Celebrity Endorser pada Jejaring Sosial Instagram untuk Menarik Minat Pembelian Calon Konsumen. Jurnal Economic Resource, 1(1), 86-96.

Rahmah, N. (2015). Pengaruh Kredibilitas Endorser Iklan Sensodyne pada Sikap Konsumen (terhadap Iklan dan Produk) dan Minat Beli Konsumen (Studi pada Mahasiswa Universitas 
Brawijaya Malang). Jurnal Ekonomi Bisnis, 20(1).

Sarashadi, G., \& Dewi, A. S. (2018). Pengaruh Penggunaan Vlogger Endorser pada Iklan dalam Membentuk Niat Beli Konsumen. Jurnal Bisnis dan Manajemen Uournal of Business and Management), 18(1), 41-52.

Sekaran, Uma \& Bougie, R. (2017). Metode Penelitian Untuk Bisnis: Pendekatan PengembanganKeahlian. Salemba Empat.

Shekari, A., Mosuavi, S., \& Gholami Chenarestan Olya, A. (2020). Explaining Model of Attitude towards Advertising in Sporting Goods via Instagram Using Technology Acceptance Model. Journal of Business Management, 12(45), 203-225.

Shimp, T. A. (2014). Komunikasi Pemasaran Terpadu dalam Periklanan dan Promosi. Salemba Empat.

Sugiyono. (2015). Metode Penelitian Pendidikan Pendekatan Kuantitatif Kualitatif dan R\&D. Alfabeta.

Tjiptono, Fandi. (2016). Pemasaran Jasa (Prinsip, Penempatan, dan Penelitian). Andi.

Wang, S. W., Kao, G. H. Y., \& Ngamsiriudom, W. (2017). Consumer's Attitude of Endorser Credibility, Brand And Intention With Respect To Celebrity Endorsement of The Airline Sector. Journal of Air Transport Management, 60, 10-17.

Zhang, X., \& Yuan, S. M. (2018). An Eye Tracking Analysis For Video Advertising: Relationship Between Advertisement Elements And Effectiveness. IEEE Access, 6, 10699-10707. 